\title{
O MESTRE VIAJANTE. RELATOS DE UM INVENTOR
}

(Resenha)

KOHAN, Walter Omar. O Mestre inventor. Relatos de um viajante educador. Tradução Hélia Freitas. 1. ed. Belo Horizonte: Autêntica Editora, 2013 (Coleção Educação: Experiência e Sentido).

\section{Samuel Mendonça* Ana Carolina Godoy Tercioti*}

Walter Omar Kohan é professor e pesquisador do Conselho Nacional de Desenvolvimento Científico e Tecnológico (CNPq) e da Fundação de Amparo a Pesquisa do Estado do Rio de Janeiro (FAPERJ). É PósDoutor em Filosofia pela Universidade de Paris 8. Em 2008, recebeu o Prêmio Cientista de Nosso Estado na área de Educação. Foi presidente do ICPIC (International Council for Philosophical Inquiry with Children), fez várias conferências no Brasil $e$ no exterior. Atualmente é professor titular da Universidade do Rio de Janeiro (UERJ) e dirige projetos na graduação, mestrado e doutorado no Programa de Pós-Graduação em Educação da UERJ e coordena projetos interinstitucionais com universidades do Brasil e da França.

\footnotetext{
* Programa de Pós-Graduação em Educação. Pontifícia Universidade Católica de Campinas.
}

A presente obra, $O$ mestre inventor. Relatos de um viajante educador, publicada em 2013, traz em seu bojo as aventuras de Simón Rodríguez por meio de suas viagens, no afã de nos mostrar a experiência que dá sentido ao ato de educar e de nos transformarmos ao mesmo tempo. $\mathrm{O}$ autor conta a história de um professor, Simón Rodríguez e de seu discípulo Bolívar, ambos empenhados em disseminar a educação popular.

A obra contém um Prólogo: Uma leitura de Rodríguez em tom de Kohan; a Apresentação: Por que e para que ler Simón Rodríguez? E os capítulos: Capítulo 0: A história de Thomas, Capítulo 1: Viajar e formarse: errância; Capítulo 2: Ensaiar a própria escola; Capítulo 3: Inventar a educação popular, Capítulo 4: A escola da antiescola: iconoclastia e irreverência; e Epílogo: Fazer escola, vida e política com Dom Simón. inventor (resenha). Revista Sul-Americana de Filosofia e Educação. Número 22: maiout/2014, p. 163-171. 
O Prólogo, Uma leitura de Rodríguez em tom de Kohan, é da lavra do professor de Filosofia da Educação Gregorio Valera-Villegas, da Universidade Central da Venezuela e da Universidade Experimental Simón Rodríguez. Da experiência do professor Rodríguez, observamos que ensinar é um desafio e é aceito por Walter Kohan para ensaiar a partir dele. Rodríguez é um viajante errante e irreverente que faz e desfaz de seus projetos, em suma, trata-se de uma narrativa de memórias. Para o Professor Gregorio, se Jacotot de Rancière é o mestre ignorante, o Rodríguez de Kohan é o mestre inventor que, apesar dos fracassos, é o errante de um projeto inacabado.

Na Apresentação, Por que e para que ler Simón Rodríguez?, o autor afirma que se alude a um livro de educação e de vida, uma viagem em busca do melhor para a educação. Trata-se de uma forma de reunir a filosofia, a educação e a vida como queria Simón Rodríguez. Vivenciamos um tempo em que a escrita parece ter se distanciado da vida e como a escrita habita o mundo acadêmico $e$ o faz alicerçada na educação e na filosofia ajuda a constatar o valor educacional e a verdade pedagógica escrita onde quer que ela se encontre na vida. $\mathrm{O}$ autor frisa que a pretensão não é alcançar a verdade, mas simplesmente uma provocação aos sentidos. Rodríguez foi professor desde jovem, político da educação, fez política pensando a escola e foi filósofo em toda a sua plenitude. Foi um leitor e um viajante contumaz. Nasceu e viveu em Caracas (Venezuela), viajou pela América Central, Estados Unidos e Europa. Em síntese, a tarefa do docente que se dedica à educação é fazer escola. Os ensinamentos de Rodríguez podem ser aplicados no século XXI, porque, conforme Kohan, o que é instaurado na vida escolar serve na educação e na vida.

No capítulo 0, A história de Thomas, o autor narra que Simón Rodríguez, de passagem pela Jamaica, na cidade caribenha de Kingston, em convívio com as crianças vem a calhar de conhecer uma que lhe chama a atenção pela criatividade e poder de invenção, Thomas. Um negrinho, analfabeto, muito pobre, mas de um raciocínio impecável, que nunca tinha ido à escola. Numa brincadeira, 
Thomas inventou uma solução para alcançar o alvo: a escada e as pessoas. Isto mexeu sobremaneira na vida de Dom Rodríguez, que o encarou como um movimento incomum e extraordinário na sua vida, tirando alguns princípios que o acompanharam pelo resto da sua vida. O pequeno não foi à escola e não foram os professores que the ensinaram. Simón não podia continuar a pensar como pensava anteriormente, porque viveu uma experiência filosófica e pedagógica de transformação. A partir do encontro com Thomas, teria uma nova vida.

No capítulo 1, Viajar e formarse: errância, o autor se reporta à viagem para a América do Norte e, em seguida, para a Europa. As coisas para Simón Rodríguez já não eram da mesma maneira após o encontro com Thomas. Rodríguez também fora enjeitado pelos pais, tal como Thomas, e a vida não teria sido tranquila para ele, mas o tio sacerdote the dera boa educação. Muito jovem lhe foi concedido o título de professor, quando assumiu o comando de um grupo de 114 crianças. No mesmo ano, casa-se com Maria de los Santos Ronco, com quem conviveria por quatro anos antes de sair de Caracas, depois não a encontrou mais. Em 1795, Simón tornou-se mestre do órfão Simón Bolívar, viveram perto por quatro anos, três anos na Europa e alguns meses ao se reencontrarem na América, quando um teve influência na vida do outro de maneira muito profunda. Dois viajantes fanáticos, as viagens os separavam e os uniam. Eles se encontraram em virtude de um conflito jurídico entre o tio e tutor de Bolívar, Carlos Palacio e sua irmã María Antonia Bolívar. Seu tio queria que María fosse educada na casa de Simón Rodríguez e ela preferia no Seminário, fugindo da casa de Rodríguez.

No ano anterior, em 1794, Rodríguez propõs à Prefeitura de Caracas sua Reforma e fez críticas a Escola de Primeiras Letras. Um sofisticado documento legal e regimental para todas as escolas do sistema escolar de Caracas. Defendeu nesse documento ainda uma escola elitista e conservadora, mas mais organizada $e$ eficaz que a já existente, sem compromisso forte com o povo, os despojados de suas terras, embora postule o direito de todos ao acesso à escola. 
Ocorre que não havia no presente documento nenhum movimento para que esse direito se efetivasse. Seu projeto foi rejeitado, sob as seguintes alegações da prefeitura: a) por não se saber do seu orçamento; b) não se necessitava de mais escolas para brancos; c) ser inadmissível que não abrissem escolas para pardos. Ressalte-se que até então Thomas não havia entrado na vida de Rodríguez. $\mathrm{O}$ seu projeto foi rejeitado, quando ele provavelmente já tinha deixado Caracas, para não mais voltar, mas seus restos mortais foram transferidos de Lima, Peru, para Caracas.

Rodríguez sai de viagem pelo mundo e Kingston foi sua primeira parada, onde conheceu Thomas, o qual mudou a sua vida radicalmente, a partir de uma escuta ao outro, ao despossuído, ao ignorado. Com a história de Thomas, ele vê a necessidade de olhar para o mundo e seus habitantes de modo diferente. Acha necessário mudar seu nome de Simón Rodríguez para Samuel Robinson, manteve as iniciais, mas a razão era proteger-se de possíveis perseguidores e esse nome o acompanha por mais de vinte anos. Da Jamaica vai para os
Estados Unidos, Europa, depois volta para a América, viajara pela Colômbia, Equador, Peru, Bolívia e Chile. Aprende várias línguas o que lhe permite compreender inglês, alemão, italiano, português, polonês, russo e francês. Buscou refletir sobre a escola e seu papel na sociedade. Nos países que visita, trabalha e estuda nos livros e na vida. Sua formação é experimental, e muito da educação popular, por isso ao voltar para América funda escolas, e também serralherias e fábricas que desenvolvem atividades relacionadas com o trabalho industrial.

Em Paris, reencontra Bolívar, e juntos visitam a Itália. Em Roma, no Monte Sacro, Bolívar jura libertar a pátria do poder espanhol. Voltam para Paris, quando Bolívar resolve voltar para a América. Rodríguez não o acompanha e vai para a Inglaterra e mais tarde, vai para Santiago do Chile, onde abre uma escola. Sua pátria não é Venezuela, como membro da Sociedade Humana, sua pátria é o mundo. De volta à América, chega a Cartagena, Colômbia, quando volta a usar seu próprio nome. Nesse reencontro com sua terra, Rodríguez tenta 
colocar em prática todas as mudanças em razão do encontro com Thomas, quando buscou fazer uma nova escola com todos e para todos, de todos. A nova escola de Rodríguez é para os que não têm condições, nem requisitos e mesmo credenciais, por isso ele foi tratado como um louco. Para seus adversários, o lugar dos Thomas não é a escola, porque entendiam ser desperdício de dinheiro público, mas Rodríguez vislumbrava que fazer escola era próprio aos despossuídos.

Ocorre que, sem condições, Rodríguez deixa o projeto e vai ao Peru em busca de Bolívar. Chega seis meses depois em La Magdalena, perto de Lima, onde Bolívar sedia seu quartel-general. Planejam juntos uma Educação Popular e viajam para o Alto Peru, para Arequipa e Cuzco e abrem escola para meninas de "qualquer classe". Na capital da Bolívia à época, em Chuquisaca, Rodríguez é nomeado Diretor de Ensino Público. O marechal Sucre fecha a escola criada por Rodríguez por entender que a escola opõe aos princípios e ao senso de educação popular. Esses revezes não o desanimam, e ele volta para Arequipa e realiza vários trabalhos quando fica sabendo da morte de Bolívar. Retorna para Lima, e em 1834 vai para o Chile, Concepción, e é convidado para ser preceptor do Instituto de Concepción. Em 1838, vai para Santiago e lá encontra com Andrés Bello, com quem compartilhou o valor da educação na América. Em Valparaíso funda uma escola $e$ reedita Luces y virtudes sociales em 1840. Vai para Lima, em 1842 , e tenta publicar toda a sua obra começando por Sociedades americanas en 1828, mas só consegue a primeira parte. Viaja para o Equador, em Quito dirige as Salinas do general Flores, venezuelano, presidente do Equador. Depois de algumas idas e vindas, em 1853, vai para Lambayeque, no Peru, e sofre um grave acidente. Em Amotape (1854), morre aos 83 anos, e seus restos mortais são levados do Panteón de los Próceres, em Lima, para Caracas, depois de cem anos de sua morte. Um mestre errante que não queria ser comparado às árvores que criam raízes, ele queria movimento, viajar. Uma das características do fazer escola para Rodríguez é a errância, que para ele significava alguém para quem as coisas não podem estar 
fixas, mas em movimento. A luta dele foi para que houvesse a inclusão dos descartados das escolas existentes. Assim, ele fazia escola, errante, errando e inventando.

No capítulo 2, Ensaiar a própria escola, o autor nos mostra que Rodríguez é complexo; seu método exige um professor que pense, invente e seja reflexivo. Ele propõe um professor que seja um artesão, um artista de seu trabalho, um inventor $e$ isso o governo não quer para as escolas. Ele assegura que esse é o caminho para a transformação, prega pensar e não imitar. Para chegarmos à verdade, precisamos inventar, não existe outro caminho; o pensamento inventivo é um recurso do poeta e também do filósofo educador. É preciso inventar uma verdade mais justa para esta terra. Outro requisito é o compromisso que tem com a infância, sua sensibilidade artística e sua capacidade de pensar. Nesse sentido, é necessário infantilizar a escola. O segredo do bom mestre é o olhar atento às crianças que o observam. Acolhê-los, atendê-los e nutri-los, isto exige sensibilidade. Viver é aprender, aprendendo.
No capítulo3, Inventar a educação popular, o autor expõe o sentimento de Rodríguez que tem Thomas como seu professor. Para Rodríguez, o primeiro significado de um professor é ajudar os outros a se encontrarem e o segundo é que as escolas desempenhem a função que lhes são próprias numa sociedade republicana. Rodríguez chama de educação geral, popular ou social a que ensina as pessoas a viverem $e$ a se tornarem autossuficientes. O professor que lhe interessa é esse que transmite um saber vital, o que o caracteriza é sua dedicação ao estudo e sua capacidade de transmiti-lo. Os professores, além dos princípios dos conhecimentos, precisam ajudar estudar, ensinar a aprender, inspirar e excitar o desejo de saber provocando uma mudança para compreender e transformar a própria vida e a dos outros. O professor deve trabalhar a atenção do aluno. Esse trabalho consiste em saber chamar, captar e fixar a atenção, para tal se exige que o professor seja "sábio, ilustrado, filósofo e comunicativo". Para Rodríguez, o trabalho do professor exige a sua sensibilidade e a dos estudantes, que deve considerá- 
los iguais, porque só há educação verdadeira entre os iguais; entre os desiguais gera antipatia e submissão. Dom Símon Rodríguez almejou um professor inspirador, que deveria ensinar divertindo e rindo sempre, sendo um excitador de saber. Ele propõe o riso como antídoto da estupidez. Dom Rodríguez vivia rindo, ensinando, escrevendo; ainda quando incompreendido, combatido, insultado e ignorado, entendia que o professor deveria rir sempre. Para o mestre viajante, o progresso pressupõe educação, a civilização é a educação da barbárie em todos os segmentos sociais. Na escola se necessita aprender o valor do trabalho, das artes e das ciências e, sobretudo, a pensar e conviver. Para ele, escola popular quer dizer escola de todo povo, com hospitalidade absoluta ao outro, ao desprezado $e$ ao estrangeiro.

No capítulo 4, A escola da antiescola: iconoclastia e irreverência, o autor nos mostra Simón Rodríguez como um irreverente, iconoclasta, pois não respeita a tradição $e$ aposta em uma educação de estudantes irreverentes, críticos, pensantes, capazes de recriar o pensamento. Os professo- res também têm que ser assim. Ele recria figuras paradigmáticas da cultura ocidental aproximando-se de nomes notáveis como Sócrates e Diógenes, o cínico. Para Sócrates, sua filosofia tem que ser educadora e o filósofo tem que ter vocação pedagógica; o filosofar se insere no educar, é uma filosofia educadora, uma escola de vida. Simón Rodríguez foi considerado por Bolívar, seu discípulo, o Sócrates de Caracas. Apesar disso, o autor destaca que Sócrates se afirma um sábio sem saber nada e Rodríguez demonstra inúmeros saberes. Sócrates elogia a ignorância enquanto Rodríguez a considera um mal social. Isso já põe em dúvida essa comparação de Bolívar. A comparação de Simón Rodríguez com os cínicos pode ser mais interessante, pois o cínico é comparado a um espião militar, vive uma vida de desprendimentos, livre e autodeterminada, um lutador, um resistente, embora para os cínicos não haja diálogo, método, pedagogia, só o valor da própria vida. Foi também observado na relação pedagógica entre Rodríguez e seu discípulo Bolívar a influência de Emílio de Rousseau. Não foi encontrado nada sobre 
Jacotot, de Rancière ( $O$ mestre ignorante) na obra de Rodríguez. Como Jacotot, Rodríguez se ocupou dos excluídos, descartados e analfabetos. Ambos queriam reverter tais situações. Jacotot considera que a emancipação só pode vir de um indivíduo para outro. Uma oposição é que Jacotot afirma uma incompatibilidade entre instituição e emancipação, que Rodríguez rejeitaria veementemente, porque para ele é por meio da educação institucionalizada que se chega à emancipação. A emancipação jacototiana é intelectual, já a de Rodriguez é emancipação social, política, ética, estética, epistemológica, ontológica, existencial. Porém, existe entre ambos, pontos comuns de interesse como: a pretensão de generalidade, confiam no ser humano sem condições, estão empenhados em governar o menos possível cada pessoa e em criar condições para que esse poder se atualize em todas as pessoas. Os dois pensam um professor que goste do trabalho, educar é formar vontades. Embora ambos tenham desenvolvido métodos específicos, subordinaram os seus métodos aos princípios e sentidos da educação. Ambos pen- saram por que e para que fazer e qual sentido do modo que educa. Rodríguez faz uma crítica à ignorância $e$ Jacotot destaca a ignorância do mestre para enfatizar a dissociação entre saber e docência.

Entre os autores latinoamericanos, Kohan aponta uma semelhança entre Simón Rodríguez e Paulo Freire, o qual é reconhecido como marco da chamada "educação popular" ou da "pedagogia da libertação", bem como o fato de ambos apostarem na alegria que deve acompanhar o ato educativo. Outros aspectos comuns entre eles: a aposta por uma educação popular e o trabalho de ambos em favor dos excluídos; seus compromissos em exercer cargos públicos; valorização da escola como instituição; defesa das condições do trabalho docente; crítica aos métodos e sistemas tradicionais de ensino; o caráter de viajantes; confiança no discurso, na crítica como forma de relação pedagógica e social. Os dois afirmaram compromisso com a educação. Paulo Freire se concentrou na alfabetização das classes populares, sobretudo dos adultos e dos camponeses, enquanto Rodríguez fixou-se 
na formação intelectual $e$ vital das crianças descartadas. A principal proximidade dos dois é que ambos são educadores para a transformação do estado de coisas.

No epílogo, Fazer escola, vida e politica com Dom Simón, o autor nos conta que a escola parece anteceder à filosofia e outras coisas que fazemos nela. Ao fazer escola Simón Rodríguez entrega sua vida de corpo e alma. É preciso ver no mestre construtor um caminho para fazer escola dentro e fora dos edifícios escolares. $\mathrm{O}$ autor destaca quatro notas no fazer escola do Mestre Construtor: errância, invenção, igualdade e irreverência. $\mathrm{E}$ enumerou outras quatro: nomadismo, alegria, povo, iconoclastia. Para os que trabalham com educação podemos multiplicar as questões, mas necessita-se que cada educador pense por si mesmo como está fazendo escola e se questionar com algumas perguntas.

Em síntese, a obra de Walter Omar Kohan, $O$ mestre inventor. Relatos de um viajante educador nos trouxe a baila um educador e filósofo interessantíssimo, do continente americano, que provoca uma reflexão sobre a educação e a escola, nos mostrando a partir de suas viagens, o mundo educacional em vários lugares e que, qualquer que seja o lugar do mundo, a educação traz a preocupação para educadores, filósofos e governo, pois a educação promove o ser humano em todas as vertentes da sua vida. A educação é o sustentáculo do sistema que o homem constrói para viver.

A obra é abrangente, portanto, interessa aos estudiosos da educação, aos filósofos e ao governo, muito particularmente aos mestres que estão na ativa e podem bebericar da filosofia de amenidades pregadas por Dom Rodríguez como o riso em quaisquer circunstâncias, afastando assim da escola o clima tenso e de cobrança. Que a aprendizagem seja sempre prazerosa, e que cada professor dê à sua escola um caráter próprio, essa foi a sua filosofia. E a vida é uma viagem, de forma que nela proporcionemos minimamente o riso. 